\title{
Efficiency of selected biocide compounds in the protection of building coatings against colonization by mold fungi, cyanobacteria and algae
}

\author{
Michał Kędzierski*), 1), Anna Wiejak²), Jolanta Janiszewska1), Anna Wiśniewska1), \\ Irena Grzywa-Niksińska ${ }^{1}$, Katarzyna Kurzepa ${ }^{1)}$ \\ DOI: dx.doi.org/10.14314/polimery.2020.5.5
}

\begin{abstract}
A series of biocidal compounds were evaluated as antifungal and antialgal additives for building coatings. The study comprised testing the susceptibility of coatings to colonization by Alternaria alternata, Ulocladium atrum, Aspergillus niger and Penicillium purpurogenum fungi as well as Nostoc commune cyanobacteria and Klebsormidium flaccidum green algae. White cabbage juice-based concentrate, dendrimeric peptides, peptide hydrolyzates from milk thistle and chestnut seeds, as well as selected ionic liquids, were used as additives to acrylic and silicone-based coatings. Also, some of biocidal additives were previously intercalated in montmorillonite or hydrotalcite to increase their wash-out resistance. The best results were obtained for the coatings modified with prolinate and sorbate ionic liquids added in the amount of $2 \mathrm{wt} \%$. They ensure protection against the algae and cyanobacteria also after aging in water for $72 \mathrm{~h}$, which indicates a possibility of their application in facade paints. Some antifungal activity was observed for the coatings containing hydrotalcite intercalated with aminododecanoic acid, while inhibition of algal growth was achieved using hydrolyzate from milk thistle seeds. However, in both cases, the coatings lost the resistance to microbial colonization when aged in water.
\end{abstract}

Keywords: biological corrosion, biocides, antifungal activity, antialgal activity, building coatings.

\section{Skuteczność wybranych związków biobójczych w ochronie powłok budowlanych przed zasiedleniem przez grzyby pleśniowe, sinice i glony}

Streszczenie: Badano skuteczność szeregu związków o właściwościach biobójczych, dodawanych do powłok polimerowych stosowanych $\mathrm{w}$ budownictwie, $\mathrm{w}$ zabezpieczaniu przed porastaniem grzybami i glonami. Wykorzystano mieszaninę grzybów testowych Alternaria alternata, Ulocladium atrum, Aspergillus niger i Penicillium purpurogenum, a także cyjanobakterie Nostoc commune oraz glony Klebsormidium flaccidum. Jako biocydy dodawane do powłokowych kompozycji akrylowych i silikonowych zastosowano: koncentrat na bazie soku z białej kapusty, dendrymeryczne peptydy, hydrolizaty peptydowe z ostropestu plamistego i nasion kasztanowca, a także ciecze jonowe. Wybrane dodatki immobilizowano na drodze interkalacji w montmorylonicie lub hydrotalkicie w celu zwiększenia ich odporności na wymywanie. Najlepszą odporność na porastanie glonami wykazywały powłoki modyfikowane dodatkiem $2 \%$ mas. cieczy jonowych z anionami prolinianowym i sorbinianowym. Ochronne działanie cieczy jonowych zachowało się również po teście wymywania wodą przez 72 h, co wskazuje na możliwość ich zastosowania w farbach elewacyjnych. Powłoki zawierające hydrotalkit interkalowany kwasem aminododekanowym wykazywały odporność na porastanie grzybami, a dodatek hydrolizatu nasion kasztanowca hamował rozwój glonów, jednak w obydwu wypadkach działanie ochronne biocydu zanikało po teście wymywania woda. Słowa kluczowe: korozja biologiczna, biocydy, działanie przeciwgrzybicze, działanie przeciwglonowe, powłoki budowlane.

Biological corrosion is a complex process of the destruction of materials by living organisms: mold fungi, algae and lichens, being an essential problem both in old and new buildings [1-3]. The major factor determining the microbial growth is an excessive and long-lasting air humidity surrounding the building materials. It may

1) ŁUKASIEWICZ Research Network - Industrial Chemistry Research Institute, Rydygiera 8, 01-793 Warsaw, Poland.

2) Building Research Institute, Filtrowa 1, 00-611 Warsaw, Poland.

*) Author for correspondence: michal.kedzierski@ichp.pl 
result from the errors at the design of construction, improper selection of the materials and finishes as well as incorrect maintenance of the building [4-6]. It is estimated that the symptoms of excessive humidity can be observed in near 15\% housing units in Poland [7].

Many microorganisms produce acidic metabolites, which can negatively affect the properties of inorganic building materials $[8,9]$. Sturm and coworkers studied the crystallization of calcium oxalate hydrates by interaction of calcite marble with fungus Aspergillus niger. They demonstrated that the formation of oxalic patina is associated with acid production by fungi and results in destruction of carbonate rocks [10]. The effect of some biogenic corrosive substances produced by the microorganisms on concrete was analyzed by Cwalina, who discussed biochemical processes essential for the mineral materials deterioration [11].

Fungi are capable of producing a variety of volatile metabolic products, including mycotoxins that may contribute to serious human health problems [12, 13], often described by the term "Sick Building Syndrome" [14]. Among the most harmful pathogens are fungi of the genera Alternaria, Aspergillus, Cladosporium, Penicillium, Fusarium, Rhizopus and Stachybotrys [7, 15]. They produce mycotoxins including trichothecenes (Stachybotrys), sterigmatocystin (Aspergillus versicolor), ochratoxin A (Penicillium and Aspergillus niger) and aflatoxin (Aspergillus flavus) [16]. Biological corrosion has also been observed in new buildings, for example, eighteen species of mold fungi were identified in acrylic coatings applied to interior walls and exterior facades [17]. In some cases, the strains resistant to commonly used antifungal agents may develop, e.g. by producing additional structural barriers limiting the interaction of the biocide with the fungal cell walls. This might be caused by improperly selected or used in an insufficient amount biocidal agent [18]. On the other hand, using high amounts of biocides or more toxic ones create environmental and human health risk. Therefore, to ensure the effective microbiological protection, an occasional change of used biocides may be necessary [19]. Because of the emergence of the strains resistant to existing antifungal agents, there is a need for seeking new biocidal substances, especially those nontoxic to humans and less harmful to the environment.

Most biocides combine bactericidal and fungicidal properties, few of them show also activity against algae, however, the mechanisms underlying the variation in the response of different microorganisms to the particular substances are still not well understood [20]. One of the most important factors influencing the susceptibility of microorganisms to the action of biocides is the chemical structure and composition of outer cellular layers. It is complex and may vary between similar types of organisms. In general, fungal cell walls contain chitin and glucan as the major components, while most algae have cell walls composed of microfibrillar cellulose, xylans and mannans $[21,22]$. The changes in the cell structure and composition may arise under different conditions of the microbial growth resulting in a different response to antimicrobial agents. Many other factors affect the biocide activity, including its concentration, adsorption and uptake into cells, accessibility of target sites, temperature and $\mathrm{pH}$ conditions [23].

A series of biocides used in our earlier studies showed high activity against bacteria and some types of fungi, however, they were not investigated for effectiveness against mold fungi and algae found in buildings. The purpose of this work was to evaluate these compounds as additives for building coatings. Among the examined substances were natural products, namely white cabbage juice-based concentrate (EC) and protein hydrolyzates from the seeds of milk thistle (HPM) and chestnut (HPC) as well as synthetic ones such as ionic liquids and dendrimeric peptides. The work included the assessment of antifungal and anti-algae effects according to the requirements for interior and exterior applications. We extended the study to examine the selected biocides previously intercalated in montmorillonite (MMT) or hydrotalcite (HT). The immobilization of biocidal compounds in such layered materials enables, in some cases, to increase their resistance to wash-out of the coating [24, 25]. The main goal of the work was to assess the applicability of the investigated compounds as environmentally friendly substitutes for currently used biocides in building paints.

\section{EXPERIMENTAL PART}

\section{Biocides}

The biocides used in the study were prepared according to the procedures referenced in the Table 1.

\section{Immobilization of biocidal additives}

The compound of montmorillonite and white cabbage juice extract (M-EC) was obtained by suspending $8 \mathrm{~g}$ Cloisite 30B (Southern Clay Products) in $50 \mathrm{~cm}^{3}$ methanolic solution of EC (3.8 wt \%), mixing and equilibration for $18 \mathrm{~h}$, then separation the product using a centrifuge. The milk thistle protein hydrolyzate with a protein content of $78-80 \mathrm{wt} \%$ and the average number of amino acid residues in the peptide molecule $n=5.5-6.0$, was used. The chestnut protein hydrolyzate contained $28-30 \mathrm{wt} \%$ protein with the average number of amino acid residues in the peptide molecule $n=2.8-3.0$

\section{Preparation of biocide-modified coating compositions}

Two coating systems were used in the study, i.e. Osakryl OSA S20, an aqueous dispersion of styrene-acrylic copolymer supplied by Synthos S.A. and Sarsil BS, silicone resin solution in organic solvent provided by Chemical Plant "Silikony Polskie" Ltd. Both binders were supplied without an additive of "in can" preservatives. The coat- 
$\mathrm{T}$ a b 1 e 1 . Biocides used in the study

\begin{tabular}{c|c|c}
\hline Designation & Compound & Reference \\
\hline SBA & Benzalkonium sorbate & {$[26]$} \\
(s)PBA & Benzalkonium s-prolinate & {$[26]$} \\
PDDM & Didecyldimethylammonium s-prolinate & {$[26]$} \\
EC & Extract from white cabbage juice & {$[27]$} \\
DP119 & Peptide dendrimer & {$[28]$} \\
ADA & Aminododecanoic acid & see Experimental Part \\
M-DP119 & Montmorillonite/DP119 intercalation compound & {$[29]$} \\
M-EC & Montmorillonite C30B/EC intercalation compound & see Experimental Part \\
HPM & Hydrolyzate peptide from milk thistle seed waste & {$[30]$} \\
HPC & Hydrolyzate peptide from chestnut seeds & {$[30]$} \\
M-ADA & Montmorillonite/ADA intercalation compound & {$[31]$} \\
HT-ADA & (Zn, Al) hydrotalcite/ADA intercalation compound & {$[32]$} \\
\hline
\end{tabular}

ing compositions were prepared by mixing acrylic or silicone binder with a predetermined amount of biocide using a homogenizer. Tables 2 and 3 show the compositions of coating specimens based respectively on aqueous styrene acrylic dispersion and silicone organic solution.

\section{Methods of testing}

Testing of susceptibility of the coatings to the growth of fungi

The effect of added biocide on fungal growth on the coating surface was measured according to PN-EN 15457:2014 standard (Paints and varnishes - Laboratory method for testing the efficacy of film preservatives in a coating against fungi). Test samples were prepared by coating a strip of filter paper without biocidal effect with the coating material to be tested. A second coating layer was applied after the first one had dried. The samples were then dried for 7 days and the specimens with size $50 \mathrm{~mm} \times 50 \mathrm{~mm}$ were cut off from them. Half of the specimens were subjected to aging by placing them in water $\left(70 \mathrm{~cm}^{3}\right.$ for each specimen) for 72 hours. Water was changed once daily.

All the specimens were sterilized using UV radiation for 24 hours, and then each of them was placed on a solidified malt-agar ( $3 \%-1.5 \%)$ culture medium, previously sterilized in the autoclave and poured into sterile Petri dish under aseptic conditions. The specimens were uniformly inoculated with $0.2 \mathrm{~cm}^{3}$ each of the mixed spore suspension, previously prepared according to the procedure specified in sub-clauses 8.2 and 8.3 of PN-EN 15457 standard. The spore suspension used for the test contained two fungi more likely to grow in an exterior environment: Alternaria alternata (DSM 62010) and Ulocladium atrum (DSM 63068), and two fungi more likely to grow in an interior environment: Aspergillus niger (DSM 12634) and Penicillium purpurogenum (DSM 62866). Pure cultures of fungi were obtained from the Deutsche Sammlung von Mikroorganismen und Zellkulturen (DSM). The specimens were then placed in
T a b l e 2. Coating compositions based on aqueous acrylic dispersion

\begin{tabular}{l|c|c}
\hline \multicolumn{1}{c|}{ Sample designation } & Additive & $\begin{array}{c}\text { Additive } \\
\text { amount } \\
\text { g per 100 g }\end{array}$ \\
\hline OSA S20 (reference sample) & - & - \\
OSA S20/SBA-2 & SBA & 2 \\
OSA S20/(s)PBA-2 & (s)PBA & 2 \\
OSA S20/PDDM-2 & PDDM & 2 \\
OSA S20/EC-1 & EC & 1 \\
OSA S20/M-DP119-2 & M-DP119 & 2 \\
\hline
\end{tabular}

$\mathrm{T}$ a b l e 3. Coating compositions based on silicone resin organic solution

\begin{tabular}{l|c|c}
\hline \multicolumn{1}{c|}{ Sample designation } & Additive & $\begin{array}{c}\text { Additive } \\
\text { amount } \\
\text { g per 100 g }\end{array}$ \\
\hline Sarsil BS (reference sample) & - & - \\
BS-DP119-1 & DP119 & 1 \\
BS/M-EC-5 & M-EC & 5 \\
BS/HPM-3 & HPM & 3 \\
BS/HPC-2 & HPC & 2 \\
BS/M-ADA-5 & M-ADA & 5 \\
BS/HT-ADA-5 & HT-ADA & 5 \\
\hline
\end{tabular}

a breeding chamber and incubated for 21 days at $24 \pm 2{ }^{\circ} \mathrm{C}$. The assessment of fungal growth was carried out visually at 7 days, 14 days and 21 days after the inoculation, using the assessment scale (EN 16492:2014):

0 - no fungal growth on the surface of the specimen;

1 - up to $10 \%$ growth on the surface of the specimen;

2 - more than $10 \%$ up to $30 \%$ growth on the surface of the specimen;

3 - more than $30 \%$ up to $50 \%$ growth on the surface of the specimen;

4 - more than $50 \%$ up to $100 \%$ growth on the surface of the specimen.

The results were taken as the average value of six samples. 
T a b l e 4. Testing of susceptibility of acrylic coatings to colonization by fungi

\begin{tabular}{|c|c|c|c|c|c|c|}
\hline \multirow{3}{*}{ Sample designation } & \multicolumn{6}{|c|}{ Assessment of fungal growth on the specimen surface } \\
\hline & \multicolumn{2}{|c|}{ After 14 days } & \multicolumn{2}{|c|}{ After 21 days } & \multicolumn{2}{|c|}{ After 28 days } \\
\hline & $\begin{array}{l}\text { Non-aged } \\
\text { samples }\end{array}$ & $\begin{array}{c}\text { Water-aged } \\
\text { samples }\end{array}$ & $\begin{array}{l}\text { Non-aged } \\
\text { samples }\end{array}$ & $\begin{array}{c}\text { Water-aged } \\
\text { samples }\end{array}$ & $\begin{array}{c}\text { Non-aged } \\
\text { samples }\end{array}$ & $\begin{array}{c}\text { Water-aged } \\
\text { samples }\end{array}$ \\
\hline $\begin{array}{l}\text { Control sample } \\
\text { (filter paper) }\end{array}$ & 4 & - & 4 & - & 1 & 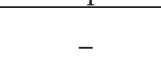 \\
\hline OSA S20 & 4 & 4 & 4 & 4 & 4 & 4 \\
\hline OSA S20/SBA-2 & 0 & 4 & 2 & 4 & 2 & 4 \\
\hline OSA S20/(s)PBA-2 & 0 & 2 & 2 & 3.7 & 4 & 3.7 \\
\hline OSA S20/PDDM-2 & 3 & 4 & 3.7 & 4 & 3.7 & 4 \\
\hline OSA S20/EC-1 & 4 & 4 & 4 & 4 & 4 & 4 \\
\hline OSA S20 /M-DP119-2 & 3.7 & 4 & 4 & 4 & 4 & 4 \\
\hline
\end{tabular}

T a b l e 5. Testing of susceptibility of silicone coatings to colonization by fungi

\begin{tabular}{l|c|c|c|c|c|c}
\hline \multirow{2}{*}{\multicolumn{1}{c|}{ Sample designation }} & \multicolumn{6}{|c}{ Assessment of fungal growth on the specimen surface } \\
\cline { 2 - 7 } & \multicolumn{2}{|c|}{ After 14 days } & \multicolumn{2}{c}{ After 21 days } & \multicolumn{2}{c}{ After 28 days } \\
\cline { 2 - 7 } & $\begin{array}{c}\text { Non-aged } \\
\text { samples }\end{array}$ & $\begin{array}{c}\text { Water-aged } \\
\text { samples }\end{array}$ & $\begin{array}{c}\text { Non-aged } \\
\text { samples }\end{array}$ & $\begin{array}{c}\text { Water-aged } \\
\text { samples }\end{array}$ & $\begin{array}{c}\text { Non-aged } \\
\text { samples }\end{array}$ & $\begin{array}{c}\text { Water-aged } \\
\text { samples }\end{array}$ \\
\hline $\begin{array}{l}\text { Control sample } \\
\text { (filter paper) }\end{array}$ & 4 & 4 & 4 & 4 & 4 & 4 \\
Sarsil BS & 4 & 4 & 4 & 4 & 4 & 4 \\
BS-DP119-1 & 3 & 4 & 4 & 4 & 4 & 4 \\
BS/M-EC-5 & 4 & 4 & 4 & 4 & 4 \\
BS/HPM-3 & 4 & 4 & 4 & 4 & 4 \\
BS/HPC-2 & 4 & 4 & 4 & 4 & 4 & 4 \\
BS/M-ADA-5 & 4 & 4 & 4 & 4 & 4 & 4 \\
BS/HT-ADA-5 & 2 & 3 & 2.3 & 4 & 4 \\
\hline
\end{tabular}

T a b l e 6. Testing of susceptibility of acrylic coatings to colonization by cyanobacteria and algae

\begin{tabular}{|c|c|c|c|c|c|c|}
\hline \multirow{3}{*}{ Sample designation } & \multicolumn{6}{|c|}{ Assessment of algal growth on the specimen surface } \\
\hline & \multicolumn{2}{|c|}{ After 14 days } & \multicolumn{2}{|c|}{ After 21 days } & \multicolumn{2}{|c|}{ After 28 days } \\
\hline & $\begin{array}{c}\text { Non-aged } \\
\text { samples }\end{array}$ & $\begin{array}{c}\text { Water-aged } \\
\text { samples }\end{array}$ & $\begin{array}{l}\text { Non-aged } \\
\text { samples }\end{array}$ & $\begin{array}{c}\text { Water-aged } \\
\text { samples }\end{array}$ & $\begin{array}{c}\text { Non-aged } \\
\text { samples }\end{array}$ & $\begin{array}{c}\text { Water-aged } \\
\text { samples }\end{array}$ \\
\hline $\begin{array}{l}\text { Control sample } \\
\text { (Filter paper) }\end{array}$ & 2 & - & 2 & - & 2 & - \\
\hline OSA S20 & 2 & 2 & 2 & 2 & 2 & 2 \\
\hline OSA S20/SBA-2 & 0 & 0 & 0 & 0 & 0 & 0 \\
\hline OSA S20/(s)PBA-2 & 0 & 0 & 0 & 0 & 0 & 0 \\
\hline OSA S20/PDDM-2 & 0 & 0 & 0 & 0 & 0 & 0 \\
\hline OSA S20/EC-1 & 2 & 2 & 2 & 2 & 2 & 2 \\
\hline OSA S20/M-DP119-2 & 2 & 2 & 2 & 2 & 2 & 2 \\
\hline
\end{tabular}

T a b l e 7. Testing of susceptibility of silicone coatings to colonization by cyanobacteria and algae

\begin{tabular}{|c|c|c|c|c|c|c|}
\hline \multirow{3}{*}{ Sample designation } & \multicolumn{6}{|c|}{ Assessment of algal growth on the specimen surface } \\
\hline & \multicolumn{2}{|c|}{ After 14 days } & \multicolumn{2}{|c|}{ After 21 days } & \multicolumn{2}{|c|}{ After 28 days } \\
\hline & $\begin{array}{c}\text { Non-aged } \\
\text { samples }\end{array}$ & $\begin{array}{c}\text { Water-aged } \\
\text { samples }\end{array}$ & $\begin{array}{c}\text { Non-aged } \\
\text { samples }\end{array}$ & $\begin{array}{c}\text { Water-aged } \\
\text { samples }\end{array}$ & $\begin{array}{l}\text { Non-aged } \\
\text { samples }\end{array}$ & $\begin{array}{c}\text { Water-aged } \\
\text { samples }\end{array}$ \\
\hline $\begin{array}{l}\text { Control sample } \\
\text { (Filter paper) }\end{array}$ & 2 & - & 2 & - & 2 & - \\
\hline Sarsil BS & 2 & 2 & 2 & 2 & 2 & 2 \\
\hline BS-DP119-1 & 2 & 2 & 2 & 2 & 2 & 2 \\
\hline BS/M-EC-5 & 2 & 2 & 2 & 2 & 2 & 2 \\
\hline BS/HPM-3 & 0 & 2 & 0 & 2 & 0 & 2 \\
\hline BS/HPC-2 & 2 & 2 & 2 & 2 & 2 & 2 \\
\hline BS/M-ADA-5 & 2 & 2 & 2 & 2 & 2 & 2 \\
\hline BS/HT-ADA-5 & 2 & 2 & 2 & 2 & 2 & 2 \\
\hline
\end{tabular}




\section{Testing of susceptibility of the coatings to the growth of cyanobacteria and algae}

The effect of added biocide on the growth of algae on the coating surface was measured according to PN-EN 15458:2014 standard (Paints and varnishes - Laboratory method for testing the efficacy of film preservatives in a coating against algae). Six test samples were prepared using the same procedure as the coatings tested for resistance to fungi.

All the specimens were sterilized using UV radiation for 24 hours, and then each of them was placed on a solidified Bold culture medium, prepared according to the procedure specified in sub-clauses 8.1 and 8.2 of PN-EN 15458 standard. The samples were flooded with a suspension of algae until completely immersed. The mixture of Nostoc commune (cyanobacteria) and Klebsormidium flaccidum (green algae) was prepared according to the sub-clauses 8.4 and 8.5 of PN-EN 15458 standard. Pure cultures of algae and cyanobacteria were obtained from the Culture Collection of Algae at the University of Göttingen (SAG). The specimens were then placed in a breeding chamber, incubated for 35 days at $23 \pm 2^{\circ} \mathrm{C}$ and irradiated with $1000 \pm 200 \mathrm{~lx}$ light intensity in a cycle of 16-hour light-period followed by 8-hour dark-period. The evaluation of algal growth was carried out visually at 14, 21 and 28 days after the inoculation, using the assessment scale:

$0-$ no growth of algae on the surface of the specimen and Petri dish;

1 - lower algal growth on the surface of the specimen containing biocide compared to the reference without biocide;

2 - similar or higher algal growth on the surface of the specimen containing biocide compared to the reference sample.

\section{RESULTS AND DISCUSSION}

For an initial screening to evaluate the potential of biocidal substances as additives for protection of building coatings against biological corrosion, an assessment method was developed [33]. It is based on EN 15457 and EN 15458 standards dealing with microbiological growth of building materials, supplemented with water aging test. The method involves the use of the selected strains of fungi likely to grow in an interior (Aspergillus niger and Penicillium purpurogenum) and exterior (Alternaria alternata and Ulocladium atrum) environment as well as Nostoc commune cyanobacteria and Klebsormidium flaccidum green algae frequently found on exterior building walls.

Two coating systems, water reducible and solventbased, were used in the study. Some of the investigated biocides, due to acidic character, caused destabilization of the aqueous dispersion, thus they were tested only as additives to the organic solvent - based system. The results of the assessment of fungal and algal growth, divided based on the coating type, are shown in the Tables 4-7.

Representative images illustrating the growth of fungi and algae (or its inhibition) on the coating specimens are depicted in Figs. 1 and 2.

Ionic liquids (ILs) became a subject of interest as substances with antimicrobial properties that are nontoxic for homeothermic organisms [34]. ILs used in this study contained quaternary ammonium cations, mainly responsible for biocidal properties and "environmentally-friendly" anions of L-proline amino acid or sorbic acid [Formulas (I) - (IV)]. Earlier studies showed that prolinate and sorbate ILs exhibit higher activity against some fungi than alkylammonium chlorides commonly used as antimicrobial agents [26, 35].

The surfaces of coatings modified with ionic liquids [SBA, (s)PBA and PDDM] used in a concentration of $2 \mathrm{wt} \%$ (based on the weight of the base coating) demonstrated a lack of algal development. This also concerned the samples subjected to immersion in water for 72 hours. In the case of fungal growth tests, the coating performance depended on the type of ionic liquid used. The best results (the growth of mold limited to $10-30 \%$ of the sample area) were obtained for coatings with added SBA and PBA, both containing benzalkonium (alkyldimethylbenzylammonium) cations. However, after aging in water, they lost antifungal resistance. Only very slight inhibition of fungal growth was observed in the case of coating with added IL containing didecyldimethylammonium cation (PDDM).

Another examined compound, extract from white cabbage juice (EC) contained the products of enzymatic hydrolysis of glucosinolates (GLS), mainly composed of isothiocyanates, nitriles and indoles. Earlier studies demonstrated the biocidal action of EC against Candida albicans and Aspergillus niger [27]. The antifungal activity of GLS degradation products was also reported by other authors [36]. In the work of Rytwo et al. [37] organically modified montmorillonite was used for adsorption of allyl isothiocyanate, the main product of GLS hydrolysis, to increase its stability and prolong its biocidal action. However, in our study, no inhibition of the microbial growth was observed for the coatings with EC extract added in the amount of $5 \mathrm{wt} \%$. This may be due to instability of $\mathrm{EC}$ bioactive ingredients or too low biocide concentration, however, further addition of EC would be impracticable due to high solvent content. Also, the negative results were obtained using EC adsorbed on organically modified montmorillonite (M-EC).

The next investigated biocide was dendrimeric peptide (DP), branched oligopeptide with structure shown in Formula (IV), successfully applied against Candida albicans yeast and various bacteria $[28,38]$. We used it alone and as a product of DP intercalation in montmorillonite [29]. In both cases, the coatings modified with DP did not show any resistance to the tested fungi and algae. 


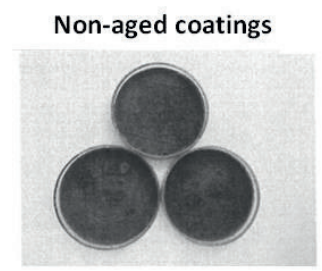

Filter paper

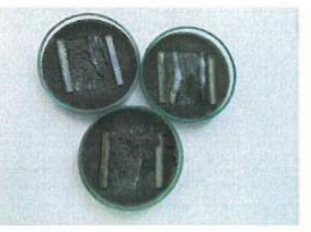

Osakryl S20-reference

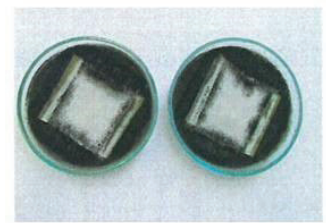

OSA S20/SBA-2

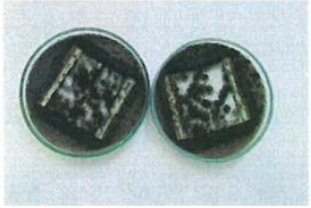

OSA S20/PDDM-2
Water-aged coatings

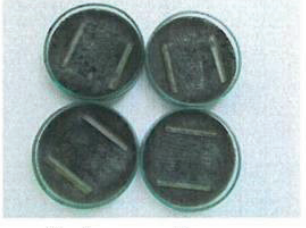

Osakryl S20-reference

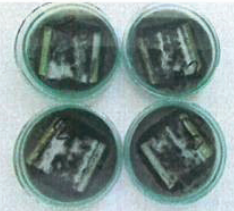

OSA S2O/SBA-2

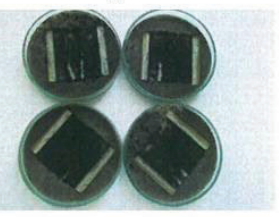

OSA S20/PDDM-2

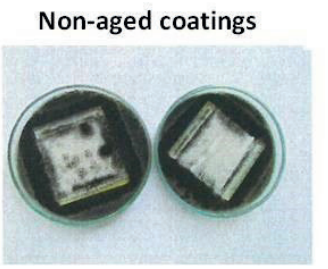

OSA S20/(s)PBA-2

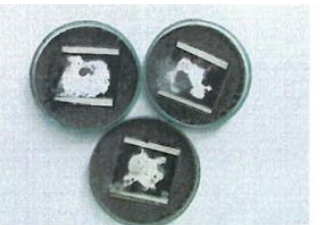

BS /M-ADA-5

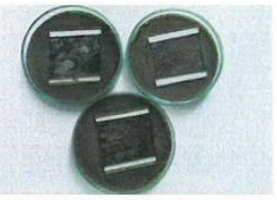

$\mathrm{BS} / \mathrm{HPC}-2$

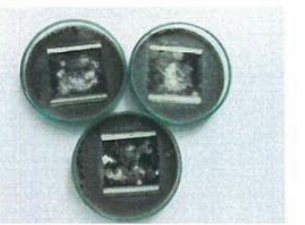

BS /M-ADA-5
Water-aged coatings

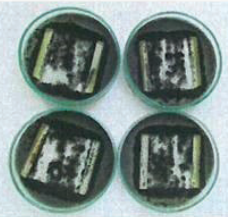

OSA S20/(s)PBA-2

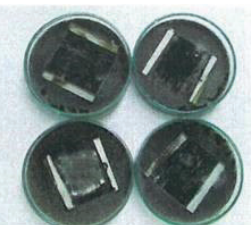

BS /M-ADA-5

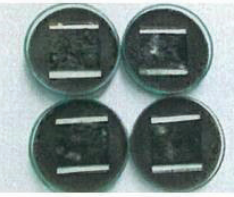

BS /HPC - 2

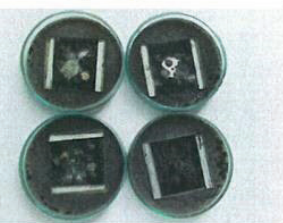

$\mathrm{BS} / \mathrm{M}-\mathrm{ADA}-5$

Fig. 1. Exemplary images of Alternaria alternata, Ulocladium atrum, Aspergillus niger and Penicillium purpurogenum fungi growth on reference and biocide-containing coatings

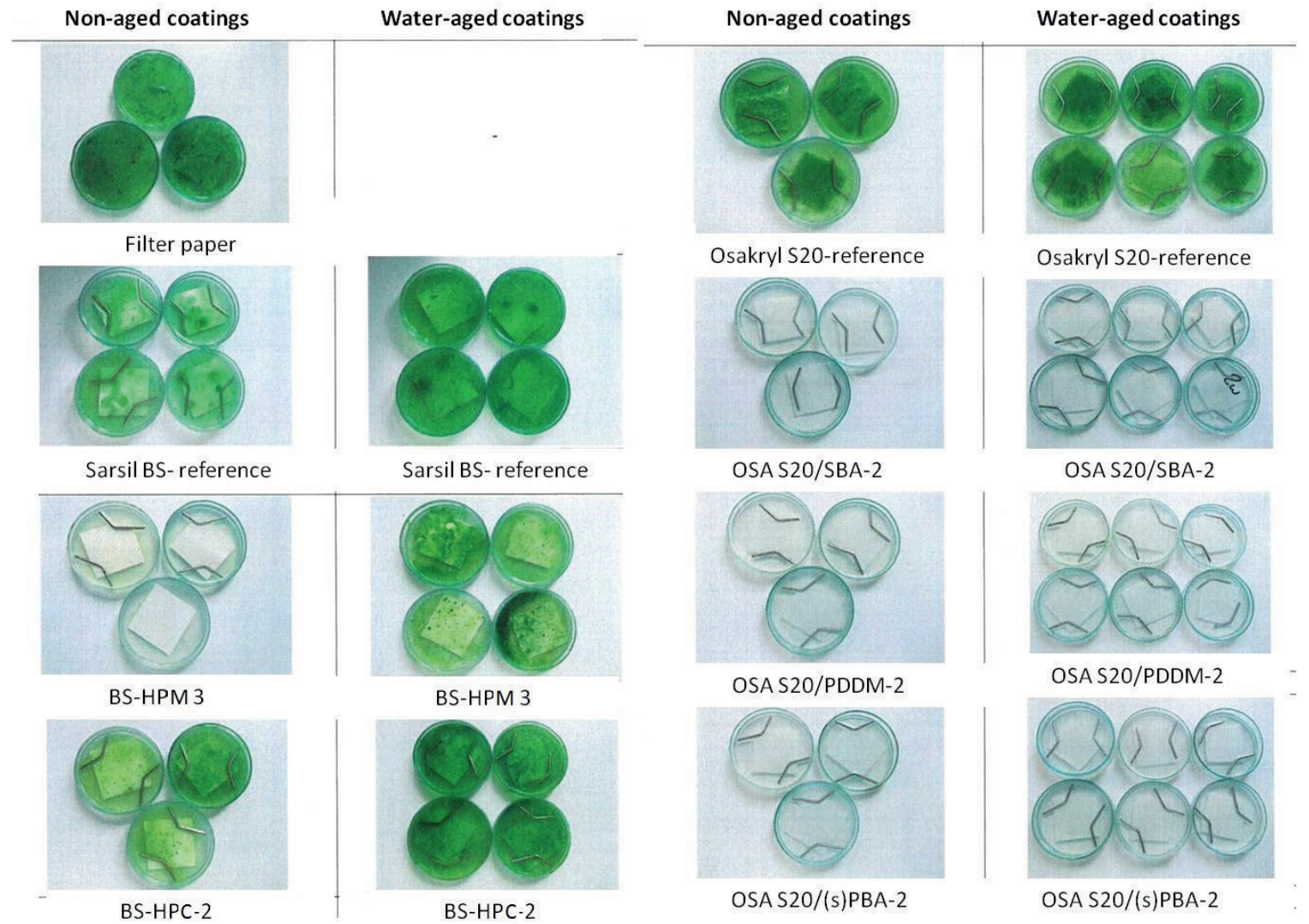

Fig. 2. Exemplary images of Nostoc commune cyanobacteria and Klebsormidium flaccidum green algae growth on reference and biocide-containing coatings 
<smiles>CCCCCC[N+](C)(C)Cc1ccccc1</smiles><smiles>C/C=C/C=C/C(=O)[O-]</smiles><smiles>CCCCCCC[N+](C)(C)CCCCCC</smiles><smiles>COC(=O)[C@H](Cc1ccccc1)NC(=O)[C@H](CCCCNC(=O)[C@H]([NH3+])CCCC[NH3+])NC(=O)[C@H]([NH3+])CCCC[NH3+]</smiles>

Other investigated peptide compounds were the products of enzymatic hydrolysis of proteins from the seeds of milk thistle and chestnut, waste materials from the herbal industry. As reported in the work of Baranowska et al. [30], the resulting hydrolyzates demonstrate the activity against most bacteria as well as fungi from the Candida family. In our experiments, only the peptide product isolated from milk thistle seeds (HPM) gave a positive result in inhibiting the growth of algae on the silicone coating, however, it showed no resistance for wash-out with water.

Layered minerals including aluminosilicates and double hydroxides (hydrotalcites) attract considerable interest as carriers for biologically active compounds, enabling their controlled release and prolonged activity [39, 40]. For example, montmorillonite clays intercalated with cationic surfactants (octadecyltrimethylammonium and hexadecy- ltrimethylammonium) showed antifungal activity against Cladosporium herbarum [41]. The study of Suslin et al. [42] showed that epoxy matrices containing montmorillonites modified by various quaternary alkylammonium ions had enhanced resistance to the biological activity of several strains of fungi, however, no fungistatic effect was observed. In our study, we used montmorillonite and zinc-aluminum hydrotalcite intercalated respectively with cationic and anionic forms of aminododecanoic acid (ADA) [31, 32]. As indicated by our unpublished data and reported in literature [43], ADA exhibits some antimicrobial properties. Additionally, due to long alkyl chain and functional end groups of ADA, its intercalation compounds with MMT and HT show good compatibility with various polymer matrices, enabling the formation of nanocomposite structures.

The silicone coating containing hydrotalcite intercalated with ADA showed a limitation of the fungal growth 
to $10-30 \%$ of the sample area. When immersed in water for 72 hours, the coating lost antifungal resistance probably due to the deintercalation of amino acid. No antifungal effect was detected for the coating contained the same amino acid intercalated in montmorillonite (M-ADA). It seems that the primary ammonium form of ADA (present in MMT) is less active than the anionic carboxylate form (intercalated in HT). The latter may act similarly as the salts of fatty acids, which display antifungal activity, especially those containing 8-12 carbon atoms in the chain [44].

\section{CONCLUSIONS}

This preliminary study showed that only a few tested substances were effective in the protection of coatings against microorganisms according to EN 15457:2014 and EN 15458:2014 standards. Additional aging tests, by water immersion for $72 \mathrm{~h}$ (not included in these standards) gave satisfactory results only for SBA, PBA and PDDM ionic liquids and only regarding the efficiency of preservatives in a coating against cyanobacteria and algae.

In contrary to peptide biocides, ILs were compatible with aqueous dispersions, not causing the emulsion breakdown. ILs with alkyldimethylbenzylammonium cations provided only temporary inhibition to the growth of fungi and lost the antifungal efficiency when the coatings containing them were subjected to water ageing. This indicates that lower concentrations of ILs are sufficient to provide biocidal action against algae than in the case of fungi.

The extract from white cabbage juice and dendrimeric peptides did not inhibit fungal and algal growth on the coating surface. Peptide hydrolyzate from milk thistle seeds and hydrotalcite intercalated with aminododecanoic acid imparted respectively antialgal and antifungal properties to the silicone coatings, however, they were not maintained after water-aging. Prolinate and sorbate ionic liquids seem to be promising as coating additives for antialgal protection, however further work is needed to analyze the leaching characteristics and long term durability of the coatings containing IL preservatives.

\section{ACKNOWLEDGMENTS}

The work was supported by the statutory funds of the Professor Ignacy Moscicki's Industrial Chemistry Research Institute and Building Research Institute in Warsaw.

The authors thank to Ms Anna Niska for excellent technical assistance in the work.

\section{REFERENCES}

[1] Piñar G., Sterflinger K.: “Building materials: properties, performance and applications" (Eds. Cornejo D.N., Haro J.L.), Nova Science Publishers, New York 2009, pp. 163-188.
[2] Gaylarde C.C., Morton L.H.G., Loh K., Shirakawa M.A: International Biodeterioration and Biodegradation 2011, 65, 1189. https://doi.org/10.1016/j.ibiod.2011.09.005

[3] Noeiaghaei T., Mukherjee A., Dhami N., Chae S.: Construction and Building Materials 2017, 149, 575. http://dx.doi.org/10.1016/j.conbuildmat.2017.05.144

[4] Pasanen A.L., Juutinen T., Jantunen M.J., Kalliokoski P.: International Biodeterioration and Biodegradation 1992, 30, 273. https://doi.org/10.1016/0964-8305(92)90033-K

[5] Adams R.I., Bhangar S., Dannemiller K.C. et al.: Building and Environment 2016, 109, 224. https://doi.org/10.1016/j.buildenv.2016.09.001

[6] Lee H.H., Oh H.R., Lim J.H., Song S.Y.: Energy Procedia 2016, 96, 601.

https://doi.org/10.1016/j.egypro.2016.09.108

[7] Wołejko E., Matejczyk M.: Civil and Environmental Engineering 2011, 2, 191.

[8] Żakowska Z: „Microbial biodegradation and biodeterioration of technical materials", IV International Scientific Conference Łódź, Conference Materials 2006, pp. 12-15.

[9] Wei S.P., Jiang Z.L., Liu H. et al.: Brazilian Journal of Microbiology 2013, 44, 1001.

h t t p s: //d x.d o i o r g / $10.1590 \%$ 2FS1517-83822014005000006

[10] Sturm E.V., Frank-Kamenetskaya O., Vlasov D. et al.: American Mineralogist 2015, 100, 2559.

http://dx.doi.org/10.2138/am-2015-5104

[11] Cwalina B.: Architecture Civil Engineering Environment 2008, 4, 133.

http://yadda.icm.edu.pl/yadda/element/bwmeta1.element.baztech-article-BSL2-0022-0118

[12] Cooley J.D., Wong W.C., Jumper C.A., Straus D.C.: Advances in Applied Microbiology 2004, 55, 1 https://doi.org/10.1016/S0065-2164(04)55001-3

[13] Gutarowska B.: „Moulds Growth and Allergens Production on Building Materials", LAP Lambert Academic Publishing AG \& Co KG, 2013.

[14] Crook B., Burton N.C.: Fungal Biology Reviews 2010, $24,106$. https://doi.org/10.1016/j.fbr.2010.05.001

[15] Żukiewicz-Sobczak W.A.: Advances in Dermatology and Allergology 2013, 30, 42. http://dx.doi.org/10.5114/pdia.2013.33377

[16] Nielsen K.F.: Fungal Genetics and Biology 2003, 39, 103. http://dx.doi.org/10.1016/S1087-1845(03)00026-4

[17] Piontek M., Bednar K.: Corrosion Protection 2011, 54, 15.

http://yadda.icm.edu.pl/yadda/element/bwmeta1.element.baztech-article-BPBA-0005-0003

[18] Stupar M., Ljaljevic-Grbic M., Subakov-Simic G. et al.: Indoor and Built Environment 2014, 23, 584. http://dx.doi.org/10.1177/1420326x12466753

[19] Langsrud S., Sundheim G., Borgmann-Strahsen R.: Journal of Applied Microbiology 2003, 95, 874. 
http://dx.doi.org/10.1046/j.1365-2672.2003.02064.x

[20] Russell A.D.: Journal of Antimicrobial Chemotherapy 2003, 52, 750 .

http://dx.doi.org/10.1093/jac/dkg422

[21] Feofilova E.P.: Microbiology 2010, 79, 711. http://dx.doi.org/10.1134/s0026261710060019

[22] Mackie W., Preston R.D.: „Algal Physiology and Biochemistry" (Ed. Stewart W.D.P.), Blackwell Sci. Publ., Oxford 1974, pp. 40-85.

[23] Russell A.D., McDonnell G.: Journal of Hospital Infection 2000, 44, 1. http://dx.doi.org/10.1053/jhin.1999.0654

[24] Nigmatullin R., Konovalova V., Gao F.: „Encyclopedia of Polymer Composites: Properties, Performance and Applications"'(Eds. Lechkov M., Prandzheva S.), 2011, pp. 567-592.

[25] Kuznetsova A., Domingues P.M., Silva T. et al.: Journal of Applied Microbiology 2017, 122, 1207. http://dx.doi.org/10.1111/jam.13433

[26] Cybulski J., Wiśniewska A., Kulig-Adamiak A. et al.: Tetrahedron Letters 2011, 52, 1325. http://dx.doi.org/10.1016/j.tetlet.2011.01.069

[27] Grzywa-Niksińska I.: Przemysł Chemiczny 2014, 93, 662.

[28] Klajnert B., Janiszewska J., Urbanczyk-Lipkowska Z. et al:: The International Journal of Pharmaceutics 2006, 309, 208. http://dx.doi.org/10.1016/j.ijpharm.2005.10.039

[29] Kędzierski M., Janiszewska J., Moszumańska I.: Polimery 2016, 61, 677. http://dx.doi.org/10.14314/polimery.2016.677

[30] Baranowska B., Kurzepa K., Marczak E. et al.: Rośliny Oleiste-Oilseed Crops 2003, 24, 725. http://www.ihar.edu.pl/biblioteka/oilseed_crops.php

[31] Kędzierski M., Penczek P.: Polimery 2004, 49, 801. http://dx.doi.org/10.14314/polimery.2004.801

[32] Kędzierski M., Bończa-Tomaszewski Z., Jaworska G., Niska A.: Polimery 2015, 60, 160. http://dx.doi.org/10.14314/polimery.2015.160

[33] Wiejak A.: Building Research Institute-Quarterly 2011, 2, 15.

[34] Foksowicz-Flaczyk J., Walentowska J.: International Biodeterioration and Biodegradation 2013, 84, 412. https://doi.org/10.1016/j.ibiod.2012.05.025

[35] PL Pat. 227245 (2015).

[36] Kaur R., Rampal G., Vig A.P.: African Journal of Agronomy 2013, 1, 017. www.internationalscholarsjournals.org

[37] Rytwo G., Moshe S.B.: Applied Clay Science 2017, 137, 30. http://dx.doi.org/10.1016/j.clay.2016.12.007

[38] Janiszewska J., Sowińska M., Rajnisz A. et al.: Bioorganic \& Medicinal Chemistry Letters 2012, 22, 1388. http://dx.doi.org/10.1016/j.bmcl.2011.12.051

[39] Eversdijk J., Erich S.J.F., Hermanns S.P.M. et al.: Progress in Organic Coatings 2012, 74, 640. http://dx.doi.org/10.1016/j.porgcoat.2011.09.029

[40] Mishra G., Dash B., Pandey S. et al.: Environmental Engineering Science 2017, 35, 247. http://dx.doi.org/10.1089/ees.2017.0062

[41] Karasa J., Nikolajeva V., Kostjukovs J.: „Organoclays - a promising antibacterial and antifungal additive to building materials", 10th Baltic States Restorers' Triennial Meeting, Latvia, Riga 27-30 May 2014, Conference Proceedings 2014, p. 240.

[42] Suslin M., Nedilko O., Mishurov D.: International Biodeterioration and Biodegradation 2016, 110, 136. http://dx.doi.org/10.1016/j.ibiod.2016.03.021

[43] Limanov V.E., Sobol A.F., Vorontsova L.M.: Pharmaceutical Chemistry Journal 2017, 5, 7. http://dx.doi.org/10.1007/bf00760837

[44] Era M., Sakai S., Tanaka A. et al.: Japan Journal of Food Engineering 2015, 16, 99. http://dx.doi.org/10.11301/jsfe.16.99

Received 17 IX 2019

\section{Sieć Badawcza Łukasiewicz - \\ - Instytut Chemii Przemysłowej im. Prof. I. Mościckiego w Warszawie \\ opracował ogólnokrajową}

\section{BAZĘ APARATURY DO OKREŚLANIA CHARAKTERYSTYKI I PRZETWÓRSTWA POLIMERÓW}

będącej w posiadaniu uczelni, instytutów PAN i instytutów badawczych.

Baza jest wyposażona w funkcje umożliwiające wyszukiwanie wg zadanych parametrów: nazwy, typu lub modelu aparatu, roku produkcji, producenta, charakterystyki parametrów technicznych, zastosowania do badań, lokalizacji, słów kluczowych, sposobu wykonywania badań, numerów norm,

wg których prowadzi się badania, oraz adresu i kontaktu z osobą odpowiedzialną za dany aparat.

Baza jest ciągle uaktualniana.

Dostęp do danych i wyszukiwanie informacji w bazie jest bezpłatne.

Instytucje i firmy zainteresowane zamieszczeniem $w$ bazie informacji o posiadanej aparaturze prosimy o przesłanie danych na adres polimery@ichp.pl 